\title{
Some Sociological, Legislative and Pedagogical Aspects of the Prevalence of Mobbing among Teachers in Primary School (Case Study)
}

\author{
Jana Goriup - Vilma Alina Šoba - Tjaša Purgaj"
}

\begin{abstract}
The paper sets forth the discussion of the occurrence of mobbing in Slovene elementary school. The study is based on empirical facts collected at three different schools. There are some differences between organizations in occurrence, victims' characteristics, the reasons and consequences of mobbing. The results of the empirical research of the psychosocial conditions in the analysed working places show that more and more teachers as employees are becoming mobbing victims. Mobbing is defined as a very strong social stress factor. Each individual or social group experiences mobbing at work as a conflict situation and communication. An attacked individual as a victim of the conflict is exposed to permanent and long-term attacks by one or more people at work. The intention of these attacks is to oust the individual from the organization or to harm him/her in other ways. A lot of pressure is being imposed on the person and also intimidation, humiliation, molestation or other negative influences appear. Because of the psychic burden the victim usually becomes ill and often leaves the working position. Mobbing can affect the individual in a way that $\mathrm{s} / \mathrm{he}$ is no longer capable of fitting into any new working environment. The most frequent consequences named by the victims are: stress, insomnia, concentration problems and family problems.
\end{abstract}

Key words: mobbing, psychological violence, emotional violence, workplace conflict, teachers.

\section{Introduction}

In the contemporary Slovenian post-modern society, the credits for work done are no longer appreciated, because we live in a society eager for quick results and outstanding achievements, as well as past achievements (often) are no longer relevant. We cannot overlook the fact that the fundamental categories of human habitation within explosive technological development, harsh economic conditions and open labor market are not intact anymore. Consequently, the individual's relationship to the achievement of universal values leads to widespread competition, individualistic orientation, all the faster pace of life and unbridled consumerism in all social subsystems, including the education.

The development of an increasingly complex post-modern society in recent decades has been marked by changes that affect the quality of human life and bring unpredictability and uncertainty to their lives. At the same time constant and increasingly unpredictable changes, which increasingly seem to be a fixture of our lives, raise questions about human life and job quality. Within these processes and trends, the work place is becoming less secure and less predictable. An individual has not been exposed to such a significant risk in a society and s/he has not had to adapt to such social circumstances yet. Today, in the post-modern reality, it is completely different, because the individuals themselves make decisions of their own life and health. This also applies to handling, understanding and "tackling" socially adverse events such as mobbing in a workplace as the labor market is undergoing major changes. Individuals should obtain information about their rights and

\footnotetext{
* Jana Goriup, University of Maribor, Faculty of Arts, Slovenia; jana.goriup@um.si

Vilma Alina Šoba, International School for Social and Business Studies, Slovenia; vilma.alina.soba@mfdps.si

Tjaša Purgaj, University of Maribor, Faculty of Arts, Slovenia; tjasa.purgaj@gmail.com
} 


\section{Acta Technologica Dubnicae \\ volume 2, 2012, issue 1}

opportunities of social and education systems. They must also provide inclusion into these, often very complicated processes. Therefore there is a requirement for a greater supply of information upon which individuals can decide, if they wish to be employed and labor organization must be interested in working effectively and taking care of the quality of their implementation.

The growing complexity of life is caused by increasing vulnerability of particular social systems and social groups of employees and requires their integration. Or, as D. Brečko (2007, p. 427) indicates, this situation is forcing us into the field "have" and thus the aspect of human "being" is neglected, which necessarily leads to strained interpersonal relationships, struggle for dominance, often driven by fear of job loss and, consequently, particularly material benefits. In such a work environment, where everyone wants to achieve only the best for themselves, one can quickly launch psychological violence against the person who threats another person on the path to the desired goal of his professional career. That also applies to employees in basic education.

\section{Mobbing as most common form of workplace violence}

The most common form of violence in the workplace, called mobbing, is widespread already everywhere and the Slovenian school place is not immune. Otherwise, a phenomenon is in the Slovenian area often equated with a description of "psychological violence in the workplace", the term originally comes from the Latin as "mobile vulgus" (Krajnc, 2010), which denotes a group of individuals with a low level of the organizational culture, and dominated by a type of destructive behavior, which is frequent among such players today. In the Anglo-Saxon-speaking environment a more established term occurs - "bullying" (as tyrannization, harassment, intimidation, and in American "harassment" (as well as or harassment, torture, disturbance, etc.). According to the current research an average of 5\% of all employees in the European Union was exposed to mobbing. M. Dodoč Fikfak et al. (2006) point out that in Slovenia we face to even a higher level of mobbing, as the proportion of mobbing victims in Slovenia ranges between 20 and 30\% and even up to $40 \%$ among employees in these intellectual institutions.

\subsection{Some basic features of mobbing}

The term mobbing was first introduced by the ethologists Konrad Lorenz (Leyman, 1993; Brečko, 2003), who observing the animals recognized the ways of their grouping, the ways they drove away the intruder or eliminated the competitor, and how individual animals behaved. In the $80 \mathrm{~s}$ of the $20^{\text {th }}$ century a Swedish psychologist of German origin, Heinz Leymann, understood the term mobbing transferred to jobs, "downloaded" it to a workplace situation and named people's aggressive behavior in a workplace (Brečko, 2003, p. 62). According to H. Leymann, mobbing is "communication full of conflict in the workplace between employees or between superiors and subordinates, while a person is attacked in a weak position (subjected to the conflict, not in the hierarchy) and subjected to systematic and prolonged attack by one or more persons with view and/or result out of the system, while under attack as a person that feels discriminated" (Leymann, 1995, p. 18).

Based on several studies H. Leymann identified 45 different acts of mobbing, which he classified into five groups according to their consequences or purposes (Kostelić-Martić, 2007, p. 27). He described the acts of mobbing as attacks on the possibility of expression and communication, on the possibility of maintaining social contacts, personal reputation, quality of work and health of the employee. C. Knorz and D. Zapf (1996, p.12-22) also mentioned the performance of individual disdained glances and gestures, refusing contact, ignoring, spreading rumors, criticizing the work, limiting the opportunities for expression, injurious questions to the victim, placing non-compliant job (far below the ability level of victims), ridicule, constant interruption of speech, intentional unavailability for the needs of victims, shouting, use of profanity, suspiciousness of psychological health of victims, verbal threats, assignment of meaningless tasks, constant allocation of new work, assignment of tasks which endanger the health of victims, attacks against political bias, criticism of private life, etc. 


\section{Acta Technologica Dubnicae \\ volume 2, 2012, issue 1}

The attacked individual experiences the destruction of social networks, because suddenly no one speaks to him/her, and when s/he addresses someone in the workplace, s/he is being ignored, transferred to another office (away from the staff); co-workers' prohibition to communicate with the victim; comprehensive ignorance of the working environment, etc. This, of course, triggers the demolition of the victim's acquired social status. H. Leymann (1995, p. 33-34) states that the demolition of victim's social prestige is marked by gossip behind his back, spreading rumors, attempts to ridicule the victim, assumptions about the victim's mental illness, attempts to coerce the victim for review by a psychiatrist, mockery of his physical defects, mimics about his mode of walking, voice or gestures in order to ridicule the victim, attacks on victim's political and religious orientation, mocking his private life, insulting the account of his ethnicity, making tasks that have a negative impact on the confidence of the victim, incorrectly assessing the work efforts to insults, questioning his/her business decisions, profanity and other expressions that do not belong into the working environment, sexual attempts or verbal sexual convergence offers, etc.

This of course leads to the destruction of the quality of professional and personal functioning of an individual, as s/he does not receive new tasks, because s/he donated all the major tasks to the extent that s/he still cannot find any task for himself/herself, and s/he is given meaningless work tasks far below the level of his/her ability, or s/he is given tasks much more often than other employees, especially those that go beyond the level of his/her qualifications in order to discredit him/her.

Due to the experience of such attacks the victim's health is also compromised since the attacks on his/her health are manifested by noxious tasks and physical violence as it is easier to exert physical violence with an apology to someone. In this way, the "discipline" is physically abused, injury or unnecessary expense are caused intentionally, psychological consequences at home or work environment are caused deliberately and sexual violence is exerted (Leymann, 1995, p. 33-34)

Other researchers (e.g., Resh, 1994; Gruban 2003, Davenport et al. 2005; Kalčič - Knavs, 2007; Zapf, 1999 , etc.) pursued the problem and found out that in the process of mobbing it is possible to identify certain developmental stages at which the conflict can develop into mobbing, which mostly results in termination of the employment relationship between the employee and employer. The situation that triggers mobbing is usually a conflict which intensifies and develops into a personal dispute. In the second phase of psychoterror, the attacks on an individual are becoming more intense. The target of attacks becomes the victim's personality. An extensive and increasing process of spreading rumors among the victim's colleagues in a workplace starts with the avoidance of communication with him/her.

This gives rise to serious and intensive development of psychosomatic disorders which are becoming more intense and more serious. The result is the individual's sickness and absence, but the manager starts (in the third stage) to implement the first disciplinary action (e.g., lower wages, in extreme cases even termination of employment). L. Weaver $(2006$, p. 8) points out that the cases of mobbing in the final stage almost always end in the termination of employment. The decision is made by the victim who cannot stand more injustice in the workplace or by the leaders.

N. Davenport et al. (2005, p. 41) even talk about the mobbing syndrome, which includes ten different factors, e. g. the assault/threat to the dignity of integrity, credibility and professionalism of employees; the denial, humiliation, intimidation, insulation, maliciously and controlled based communication; and removing a person from his/her environment presented as his/her free decision. They appear in various combinations, systematically and repeatedly, so their impact on the victim becomes the main element of mobbing syndrome:

- they operate directly or indirectly in an insidious or obvious way, as mobbing is caused by one or more employees;

- they occur continuously, repeatedly and systematically over a certain period;

- the victim is marked in such a way that $\mathrm{s} / \mathrm{he}$ is at fault; 


\section{Acta Technologica Dubnicae \\ volume 2, 2012, issue 1}

- they build on a person's shame and confusion;

- the victim is frightened, isolated and plunged in obedience;

- they act in order to displace the victim.

As such actions are not identified, they are misinterpreted, ignored, tolerated, encouraged, or even instigated by the management organization (see also Tuškej, 2007, p. 26-27).

\subsection{Forms of mobbing}

Regardless of whether mobbing is going on at the same or different hierarchical level we distinguish two forms of mobbing. When the attacker and the victim are at the same hierarchical level we are talking about the horizontal mobbing. However, if they are acting at different hierarchical levels we are talking about the vertical mobbing, within which occur strategic mobbing and "staffing" (KostelićMartić, 2007, p. 27-28). Today the virtual mobbing or e-mobbing are more and more frequent forms of mobbing.

\begin{tabular}{|c|c|c|}
\hline \multicolumn{3}{|l|}{ 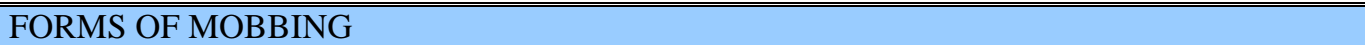 } \\
\hline HORIZONTAL & \multicolumn{2}{|l|}{ VERTICAL } \\
\hline \multirow{3}{*}{$\begin{array}{l}\text { Employees at the same } \\
\text { hierarchical level. }\end{array}$} & \multicolumn{2}{|c|}{ Employees at different hierarchical levels. } \\
\hline & STRATEGIC MOBBING & "STAFFING" \\
\hline & $\begin{array}{l}\text { Superiors } \\
\text { Leadership } \rightarrow \text { Subordinated }\end{array}$ & $\begin{array}{l}\text { Subordinated } \rightarrow \\
\text { Superiors Leadership }\end{array}$ \\
\hline
\end{tabular}

Table 1 Forms of mobbing

\subsubsection{Horizontal mobbing}

In this form of mobbing employees' position in the company is equal and they are trying to get rid of another employee by various negative acts. Feeling threatened, jealousy or envy can be stimulated to get rid of the employee. Especially, if those who carry out mobbing think it might help them in their advancement in professional careers. In other cases of the horizontal mobbing, a group of employees in the company exercises violence against one of the members of this group, who is chosen as a "sacrificial lamb". The reasons for mobbing are similar to the example above: that the attacker/s are committing acts of violence to hurt the victim, because they feel threatened which incites envy and jealousy in them. With humiliation, insults or other harassment they annoy the individual mentally; they actually glorify themselves and act out their own frustration and try to demonstrate that they are stronger and more capable than the victim (Kostelić-Martić, 2007, p. 27-28).

\subsubsection{Vertical mobbing}

Psychological violence occurs between a superior(s) and a subsidiary, or group of subordinates. These are acts of violence made between employees at different hierarchical levels. In this context, the role of aggressor and the victim are changeable; once one, another time the other. When a superior tries to remove someone to a lower position we talk about the strategic mobbing. The attacked individual may occur as a surplus after the reorganization, acquisition or merger. It may also happen that the victim simply cannot adapt to the changes made within the company and cannot be incorporated into the new environment. As such, the employee is obviously undesirable, so the systematic psychological violence usually precedes his/her termination. The superior deliberately uses violence, insults and humiliates the subordinate, and in this way s/he tries to get rid of the victim (Kostelič-Martić, 2007, p.27-28). 


\section{Acta Technologica Dubnicae \\ volume 2, 2012, issue 1}

The opposite situation is possible, when a group of subordinates carries out psychological violence against the superior, in this case a victim of mobbing. This type of violence in the workplace is called "staffing". The Slovenian translation does not exist for it yet, but it could be described as group mobbing, working or mobbing up. Such cases are rare, but they occur mainly in those cases where employees want to get rid of their boss (Bakovnik, 2006, p. 4).

There are two other forms of mobbing that researchers rarely mention. The first one is the so-called "bullying" (Einarsen - Skogstad, 1996), which characterizes cruel, inhuman superiors' behavior to subordinates within the organization, with the purpose to humiliate the subordinate and to demonstrate the superiority and domination over the individual or group of individuals. This behavior occurs when the superior feels that his/her subordinates carry out their work better than him/her. So s/he begins to punish the subordinate with constant criticism or confiscation of the responsibility and competence.

S/he often refuses to share any information relevant to business with anyone, because $s /$ he believes that no one is trustworthy. With an elevated tone s/he forces the subordinate employees to meet the claim and insists that his/her methods and tasks of work execution are the best. In some Englishspeaking countries the terms bullying and mobbing are often equated and used as synonyms (Mlinarić, 2007). Another form is "bossing" (Brinkmann, 1995) which indicates mobbing by the superior, although not as brutal, but this does not mean a less intensive process. When the boss is a mobber, the victim has no chance to escape from this circle which means that he is already ready for "shooting".

\subsection{Reasons for the emergence of mobbing}

The causes of mobbing are multifaceted, complex and simultaneous. They do not occur only with the individual, but also in work organization and society. D. Brečko (2007, p. 420) connects mobbing preconditions with mismatch in the organization (because of the rigid hierarchy, low levels of decisionmaking, underestimation of employee skills and vacancies), inadequate management styles (e.g. authoritarian way, risk-tolerant obvious signs of violence), social status of the mobbed (and their cultural and national origin, color, sex); exercises of power, strengthening the cohesion within the group, fear of job loss and dissatisfaction in the workplace. A. Cvetko (2006, p. 33) lists the particular external causes of the mobbing development and points out the market competition, globalization, major organizational changes (privatization, mergers, restructuring, etc.), the economic crisis and others. That certainly raises resulting feelings of employment insecurity and increases expectations of organization's and employees' flexibility.

\subsection{Mobbing victims and perpetrators (mobbers)}

Anyone in employment can be a mobbing victim. A. Kostelić-Martić (2007, p. 28) and D. Brečko (2007, p. 421) noted that the victims of mobbing are mostly "honest" individuals, who have observed and reported irregularities in the work place; young people, starting a professional career or just busy people, as well as those prior to retirement, who have slowed the rhythm of work, with reduced motivation for new forms of vocational training and/or have too high incomes; people who want new working tools (new computers, new software) and more autonomy in work; people who after many years of efficient work required recognition of their status, working conditions and higher wages, individuals identified as surplus labor; highly creative individuals; employees with physical disabilities; employees who are frequently absent from work due to illness or are on sick leave; members of the opposite sex who are in clear minority; individuals and/or who practice a different sexual orientation.

Mobbing researchers (e.g., Brečko, 2006; Leymann, 1993; Zuschlag, 2001; Niedl, 1995; Einarsen Skogstad, 1996; Zapf, 1999; Namie, 2000; Cvetko, 2006; Davenport et al., 2006) estimated that most mobbers are people with personality disorders, also less capable, but with strong personality without the ability to love, joy and play; without creativity, not capable of giving and sharing. As strong personalities they can easily be joined by other "bad" people, in fear of not becoming victims and 


\section{Acta Technologica Dubnicae \\ volume 2, 2012, issue 1}

trying to avoid mobbing situation. They identify themselves with a mobber or embark on his side. With creation of mobbing they want to disguise the weakness in another sphere of their lives (mostly private). Thus, they form a group around him in which they prove their strength and importance on the expense of victims.

Mobbing researchers describe different types of mobbers as socially dysfunctional, of inferior potential, egocentric persons, professionally dysfunctional, as guru and sociopaths (Koić, 2006, p. 187-195). But in fact, mobbers very often feel inferior (each overpotention is hiding an impotence). They want to play a more dominant role and push away anyone who stands in the way to their success. This should be done from a personal fear that they will not be appreciated or even that they will become victims of mobbing themselves. Some mobbers function consciously with the intention to harm someone or to compel him to leave the job. This occurs when they feel threatened (e.g. in career), or in a situation, where the working organization perceived problems with surplus labor, which will require reducing the employees. However, mobbing in the initial phase often happens unconsciously. Thus, some people begin to mob the others simply because they do not know how to behave differently within the group.

In many cases, the main mobbers' feature is their egocentrism. They are convinced that they must be given everything what they need by the others who should be grateful to them. Such individuals do not have empathy and cannot understand the others' feelings. They often state that they are the victims and that the others attack them. They behave very amiable to authority, excessively servile to the colleagues, emotionally immature and selectively friendly. Being discovered they claim that they are the victims, but when being asked to admit responsibility, they blame the others and always want to be in the spotlight.

D. Brečko (2007, p. 421) also notes that the attackers are in $44 \%$ of cases the staff members, in $37 \%$ the superiors, in $10 \%$ the superiors and subordinates at the same time and in $9 \%$ of cases the subordinates. A. Kostelić-Martić $(2005$, p. 18) states that the perpetrators torture the victims because of the sense of jealousy, envy, fear, uncertainty and antipathy. The offenders may also be individuals, who feel that their reputation and position in the work organization is at risk.

\subsection{Consequences of mobbing}

Mobbing is a psychological violence in the workplace and, as such, it is one of the most insidious forms that decomposes economic and social security, dignity, mental and physical existence of an individual and normal functioning of social processes (Kečanović, 2006, p. 23). The consequences of mobbing are, just as the causes, very diverse, complex and unpredictable. Mobbing can cause very negative consequences in complex work organizations and, consequently, in the global society. Marais-Steinman $(1998$, p. 4) notes that mobbing in the workplace causes immediate and often longterm disruption of interpersonal relations in work organization and work environment in general, which usually results in reduction of service quality and loss of productivity and efficiency. Also, because the victims of mobbing from spend $10 \%$ to $52 \%$ of their time on planning defense strategy, survival strategies and maneuvering in the organization.

Absenteeism, most often due to the victim's illness, is critical for the employers. Further loss for the victim represents the dismissal of work relationship. At the global level mobbing in companies may eventually result in unemployment and psychological and physical problems that affect the victim's social status. Consequently, the costs are also reflected in the cost of health care and long-term rehabilitation for reintegration of victims, the costs of unemployment and retraining of victims and the costs of disability and disability among the victims whose working capacity is reduced due to the violence. Mobbing also influences the employees who are (silent) witnesses of a hostile attitude. These events are usually only (powerlessly) observed, but there are rarely found those who try to stop the perpetrator. Although the witnesses of violence are not directly related, but feel the effects, namely: guilt, fear of consequences in the event that would help the victim, fear that they may become victims themselves, retreat or avoidance of the offender not to attract his attention, imitation of committed act 


\section{Acta Technologica Dubnicae \\ volume 2, 2012, issue 1}

in order to avoid the role of potential victims or even to achieve success, joining the offender (e.g., for promotion). Acts of mobbing are mentally so tiring that they leave serious consequences for an individual, work colleagues and the victim's family. The organization itself and the society also feel the consequences of bullying.

\begin{tabular}{|c|c|c|c|}
\hline $\begin{array}{l}\text { Consequences for } \\
\text { an individual }\end{array}$ & $\begin{array}{c}\text { Consequences for } \\
\text { the staff and co- } \\
\text { workers }\end{array}$ & $\begin{array}{c}\text { Consequences } \\
\text { for the organization }\end{array}$ & $\begin{array}{l}\text { Consequences } \\
\text { for the society }\end{array}$ \\
\hline $\begin{array}{c}\text { depression, } \\
\text { sleep disorders, } \\
\text { heart problems, } \\
\text { social security threat, } \\
\text { loss of self-respect, } \\
\text { distorted interactions, } \\
\text { suicide }\end{array}$ & $\begin{array}{l}\text { negative impact on } \\
\text { working conditions, } \\
\text { productivity and results, } \\
\text { reduced job satisfaction, } \\
\text { increased mistakes, } \\
\text { absence of motivation for } \\
\text { work }\end{array}$ & $\begin{array}{c}\text { increased absenteeism, } \\
\text { lower efficiency and } \\
\text { productivity, } \\
\text { financial and human } \\
\text { losses, } \\
\text { loss of reputation }\end{array}$ & $\begin{array}{l}\text { increasing healthcare } \\
\text { costs, } \\
\text { losses in the pension } \\
\text { system, } \\
\text { increased unemployment } \\
\text { in the country, } \\
\text { lower productivity in the } \\
\text { entire society }\end{array}$ \\
\hline
\end{tabular}

Table 2 Consequences of mobbing

We note, however, that the power and higher frequency of mobbing is detected not only in the private sector but also in the public sector, which also includes the educational system. Women are more likely to be found among the victims and men more often among perpetrators. Psychological violence exist at all organizational levels the agents being both superiors and colleagues. We often coope with multiple agents; in this case, violence is even longer.

\section{Methodology}

\subsection{Research objectives}

Because mobbing is a repeated, deliberated, offensive and hostile behavior directed to the victim as a target, we were interested in the fact whether such socially undesirable processes take place in the Slovenian school system. According to the research done so far, mobbing is frequent mostly in public institutions (Parent-Thirion, 2007; Skrilec, 2008; Brečko, 2006). We wanted to know what dimensions of psychological violence in the workplace are detected or experienced by the teachers in Slovenian elementary education subsystem.

In the survey among the primary school teachers of different gender and age we wanted to find out:

- Are they familiar with the phenomenon of mobbing?

- Which role did they encounter with in mobbing?

- How were they treated being the victim?

- Who were the mobbers?

\subsection{Research method}

The survey was based on the descriptive and causal non-experimental method - empirical social science research. 


\section{Acta Technologica Dubnicae \\ volume 2, 2012, issue 1}

\subsection{Research model}

We employed a quota-type sample (n-106) reflecting the primary school population in Slovenia. Regional school distribution was also taken into account. The current study included 89 female teachers $(84 \%)$ and 17 male teachers $(16 \%)$ as the feminised nature of the school field was entirely expected. The interviewed teachers were divided into three age groups: up to 34 years $(24.5 \%)$, from 35 to 54 years $(67.9 \%)$ and over 55 years $(7.5 \%)$.

\subsection{Research hypotheses}

The research hypotheses were implicitly expressed in the form of research questions about dependent associations or differences.

\subsection{Procedure of data collection and processing}

The necessary empirical data were obtained by interviewing the elementary teachers, which was conducted during December 2009-March 2010. The principals of elementary schools were first asked to participate, and after they agreed, we carried out the interviews anonymously and collectively-run with the previous guidance and request for participation. All the questions in the questionnaire were closed-type questions. The obtained empirical data were processed with the statistical software package SPSS. We calculated the absolute (f) and percentage (f \%) frequencies, and the resulting tabular data display. For the verification of dependent relationships between the variables, we used the $\chi 2$-test.

\section{Results and interpretation}

\subsection{Familiarity with the process of mobbing}

The obtained empirical data showed that the majority of respondents are familiar with the concept of mobbing. 91 teachers (85.5\%) have and only 15 teachers (14.2\%) have not heard about mobbing. The result was expected because nowadays the media very often report about violence at work. During the research, the new Penal Code (Official Gazette, No. 29) came into force, in which mobbing was defined as a crime, and the frequency of occurrence of mobbing presentation to the public was very high.

\begin{tabular}{|c|c|c|c|c|c|c|c|c|c|c|}
\hline \multirow{3}{*}{$\begin{array}{c}\begin{array}{c}\text { Familiarity } \\
\text { with mobbing }\end{array} \\
\text { Yes }\end{array}$} & \multicolumn{2}{|c|}{ Male } & \multirow{2}{*}{\multicolumn{2}{|c|}{$\begin{array}{l}\text { Female } \\
\text { f\% }\end{array}$}} & \multirow{2}{*}{\multicolumn{2}{|c|}{$\begin{array}{c}\text { Up to } 34 \text { years } \\
\text { f } \quad \mathbf{f} \%\end{array}$}} & \multicolumn{2}{|c|}{ 35-54 years } & \multicolumn{2}{|c|}{ Over 55 years } \\
\hline & f & $\mathbf{f} \%$ & & & & & & f \% & $\mathbf{f}$ & f \% \\
\hline & 16 & 94.1 & 75 & 84.3 & 25 & 96.2 & 62 & 86.1 & 4 & 50.0 \\
\hline No & 1 & 5.9 & 14 & 15.7 & 1 & 3.8 & 10 & 13.9 & 4 & 50.0 \\
\hline Total & 17 & 100.0 & 89 & 100.0 & 26 & 100.0 & 72 & 100.0 & 8 & 100.0 \\
\hline$\chi^{2 \text {-test }}$ & & $1.64, \mathrm{~g}$ & $p=$ & & & & 840 & $2, p=$ & & \\
\hline
\end{tabular}

Table 3 Number $(f)$ and percentage ( $f \%$ ) of teachers' familiarity with the concept of mobbing by gender and by age

As the result of the first $\chi 2$-test shows, the null hypothesis is retained. Statistically significant difference between the sexes upon familiarity with the concept of mobbing does not exist. Most of the men $(94.1 \%)$ as well as female respondents surveyed (84.3\%) are aware of mobbing, as we expected. We expected that gender has no significant effects on familiarity with the concept of mobbing.

We noted a statistically significant difference in the teachers' age so the outcome of $\chi 2$-test shows that the null hypothesis can be rejected as. Elderly teachers were less familiar with the concept of 


\section{Acta Technologica Dubnicae \\ volume 2, 2012, issue 1}

mobbing. In the group up to 34 years $96.2 \%$ of surveyed teachers knew mobbing, while among those over 55 years of age, only $50 \%$.

This result was not expected, because we assumed that the age of the respondents would not affect the teachers' familiarity with the model of mobbing as a complex and aggressive violence. This result is probably due to different concepts, understanding and perception of workplace violence, as in the Slovenian area there is only one technical term for the concept of this form of violence. As the elderly respondents heard about the term "harassment" and "workplace bullying", they were not really familiar with the term "mobbing" in a recent context and concept.

\subsection{The role which the teachers encountered with in the process of mobbing}

\begin{tabular}{|l|c|c|}
\hline Role in the process of mobbing & f & f\% \\
\hline Observer & 19 & 17.9 \\
\hline Victim & 15 & 14.2 \\
\hline Offender & 3 & 2.8 \\
\hline None of these & 69 & 65.1 \\
\hline Total & 106 & 100.0 \\
\hline
\end{tabular}

Table 4 Number $(f)$ and percentage $(f \%)$ of teachers' role in the process of mobbing

15 surveyed teachers (14.2\%) said that they (already) have been or still are a victim of bullying at the workplace. This proportion was surprisingly high, suggesting that at least one of seven respondents has already been exposed to mobbing. If we analyze the percentage of respondents, who have witnessed mobbing, the information is even more alarming. We noticed 19 observers $(17.9 \%)$ of mobbing development. If we combine these figures, we find out that a third of all surveyed teachers have been subjected to mobbing. Thus it can be concluded that the harassment at workplace is in the school environment present! Three surveyed teachers even admitted that they had implemented mobbing. Only $69(65.1 \%)$ surveyed teachers have not met psychological violence in any of these applications yet. This suggests that mobbing is a serious problem in the subsystem of Slovene primary education and that it should be investigated and eliminated as soon as possible.

\begin{tabular}{|c|c|c|c|c|c|c|c|c|c|c|}
\hline \multirow{2}{*}{$\begin{array}{l}\text { The role in the } \\
\text { process of } \\
\text { mobbing }\end{array}$} & \multicolumn{2}{|c|}{ Male } & \multicolumn{2}{|c|}{ Female } & \multicolumn{2}{|c|}{ Up to 34 years } & \multicolumn{2}{|c|}{ 35-54 years } & \multicolumn{2}{|c|}{ Over 55 years } \\
\hline & f & & f & $\mathrm{f} \%$ & & $\mathbf{f} \%$ & & & & \\
\hline Observer & 3 & 17.6 & 16 & 18.0 & 3 & 11.5 & 14 & 19.4 & 2 & 25.0 \\
\hline Victim & 2 & 11.8 & 13 & 14.6 & 2 & 7.7 & 10 & 13.9 & 3 & 37.5 \\
\hline Offender & 1 & 5.9 & 2 & 2.2 & 0 & 0.0 & 3 & 4.2 & 0 & 0.0 \\
\hline None of these & 11 & 64.7 & 58 & 65.2 & 21 & 80.8 & 45 & 62.5 & 3 & 37.5 \\
\hline Total & 17 & 100.0 & 89 & 100.0 & 26 & 100.0 & 72 & 100.0 & 8 & 100.0 \\
\hline$\chi 2$-test & \multicolumn{4}{|c|}{$\chi^{2}=0.627, \mathrm{~g}=3, \mathrm{p}=0.890$} & \multicolumn{6}{|c|}{$\chi^{2}=8.415, \mathrm{~g}=6, \mathrm{p}=0.209$} \\
\hline
\end{tabular}

Table 5 Number $(f)$ and percentage ( $f \%$ ) of teachers' role to in the process of mobbing by gender and by age

Based on $\chi 2$-test we found out that in both cases, the null hypothesis is retained, which means that regardless of the teachers' gender and age, we cannot talk about the existence of statistically significant differences of the role in the process of mobbing.

We find that the relatively equal shares by gender roles are distributed. Thus, $11.8 \%$ of male and $14.6 \%$ of female responders have already experienced mobbing. Only $17.6 \%$ male and $18.0 \%$ female respondents confessed being the observers or witnesses of mobbing acts. Male respondents (5.9\%) prevailed among the perpetrators while the proportion of female respondents was slightly lower (2.2\%). The result was not expected since other studies in our country and in other countries (e.g., Parent-Thiron et al., 2007, p. 101) have revealed that women are frequently found in the group of victims, which was not confirmed in our study. 


\section{Acta Technologica Dubnicae \\ volume 2, 2012, issue 1}

The detailed examination of frequencies shows small differences in responses between different aged respondents. We noted that with the age of respondents, the number of the victims and observers of mobbing actions was rising. Thus, we conclude that the surveyed teachers over 55 years were and are the most vulnerable group as $37.5 \%$ of them have already found themselves in the role of victim. Among those aged up to 34 years, $7.7 \%$ identified themselves as victims. With higher age, the number of those who have already witnessed mobbing rises. In the age up to 34 years $11.5 \%$ of the surveyed teachers have witnessed the harassment in the workplace; in the middle age group 19.4\%, and among those over 55 years, $25.0 \%$. All three offenders of mobbing captured by our survey were in the group from 35 to 54 years old.

Such an outcome was expected, as older teachers who are about to retire, are, slower is their pace of work, they have less incentive for new forms of vocational training than their younger counterparts and they receive higher wages. All this disturbs younger teachers who are refusing such mode of work behaviour and to whom the older teachers are often "in the way" in implementing new approaches, techniques and teaching methods, as they refuse teamwork and reject younger colleagues' proposals.

\subsection{The mode of treatment in case of mobbing victims}

\begin{tabular}{|l|c|c|}
\hline The mode of treatment & f & f\% \\
\hline Sick leave & 8 & 7.5 \\
\hline Service replacement & 26 & 24.5 \\
\hline Taciturnity, secrecy & 20 & 18.9 \\
\hline Discretion, severance & 6 & 5.7 \\
\hline Lamentation & 46 & 43.4 \\
\hline Total & 106 & 100.0 \\
\hline
\end{tabular}

Table 6 Number $(f)$ and in percentage ( $f \%$ ) of teachers' conduct in case of being a victim

46 of teachers surveyed (43.4\%) said that if they had been affected by mobbing, they would have filed a lawsuit against the offender. The results are consistent with the answers about the respondents' familiarity with the Article in the new Criminal Code (KZ-1, Uradni list RS št. 55), which defines mobbing as a crime, as about $40 \%$ of the respondents was familiar with it. Those familiar with the novelty would most likely bring the action. Almost a quarter of teachers $(24.5 \%)$ would decide to change the workplace; 20 (18.9\% would choose secrecy and would have accustom to the situation by saying "there is not better elsewhere". We estimate that this is the worst possible solution, so we were, on the one hand, surprised. On the other hand, under the current harsh social conditions most employees are afraid of losing their jobs, so they do not want to be exposed to other problems or even to deep the existing ones. 6 surveyed teachers $(5.7 \%)$ would wait for the employer to dismiss them from work so they could be given the severance pay, 8 of them $(7.5 \%)$ would have stayed on a longer sick leave.

\begin{tabular}{|c|c|c|c|c|c|c|c|c|c|c|}
\hline \multirow{2}{*}{$\begin{array}{l}\text { The method of } \\
\text { handling }\end{array}$} & \multicolumn{2}{|c|}{ Male } & \multicolumn{2}{|c|}{ Female } & \multicolumn{2}{|c|}{$\begin{array}{c}\text { Up to } 34 \\
\text { years }\end{array}$} & \multicolumn{2}{|c|}{$35-54$ years } & \multicolumn{2}{|c|}{$\begin{array}{c}\text { Over } 55 \\
\text { years }\end{array}$} \\
\hline & $\mathbf{f}$ & $\mathbf{f} \%$ & f & $\mathrm{f} \%$ & & fs & $\mathbf{f}$ & $\mathbf{f} \%$ & $\mathbf{f}$ & f\% \\
\hline Sick leave & 0 & 0.0 & 8 & 9.0 & 0 & 0.0 & 6 & 8.3 & 2 & 25.0 \\
\hline Service replacement & 3 & 17.6 & 23 & 25.8 & 11 & 42.4 & 15 & 20.8 & 0 & 0.0 \\
\hline Taciturnity, secrecy & 4 & 23.5 & 16 & 18.0 & 1 & 3.8 & 15 & 20.8 & 4 & 50.0 \\
\hline Discretion, severance & 1 & 5.9 & 5 & 5.6 & 0 & 0.0 & 5 & 6.9 & 1 & 12.5 \\
\hline Lamentation & 9 & 52.9 & 37 & 41.6 & 14 & 53.8 & 31 & 43.1 & 1 & 12.5 \\
\hline Total & 17 & 100.0 & 89 & 100.0 & 26 & 100.0 & 72 & 100.0 & 8 & 100.0 \\
\hline$\chi 2$-test & $\chi^{2}$ & $.846, \mathrm{~g}$ & $4, p$ & 427 & & $\chi^{2}=$ & 356 , & $8, p=$ & & \\
\hline
\end{tabular}

Table 7 Number $(f)$ and percentage ( $f \%$ ) of teachers' replies on a topic of hypothetical reaction to mobbing (in case of being a victim) by gender and by age 


\section{Acta Technologica Dubnicae \\ volume 2, 2012, issue 1}

We found out that there are no statistically significant gender differences in the way of victims' conduct in case of mobbing. The null hypothesis, based on the $\chi 2$-test, is retained. The overview of frequencies showed that $52.9 \%$ of male and $41.6 \%$ of female respondents would bring an action against the perpetrators. The result is encouraging as people are increasingly aware that they need to fight for their rights and ultimately for their health. Surprisingly, the longer sick leave would not be chosen by any male respondent, but this option would be chosen by $9 \%$ of female respondents. $18.0 \%$ of female and $23.5 \%$ of male respondents would keep silent about the unpleasant and abusive events, $25.8 \%$ of female and $17.6 \%$ of male respondents would seek another job.

Such an outcome was not expected, since we assumed that the shares in the category of secrecy would not have been so high. If we keep silent about the problem, do not entrust it to the others or do not act, then the existence of a latent threat of the already intolerable situation is a message to the offenders that we approve of their actions or that we are afraid of them. This is definitely good neither for the individual's health nor for the quality of work. The silence often leads to serious health problems, depression, trauma, resulting in disability retirement or the victim simply cannot find a way out of such situations and the possibility of suicide increases.

The null hypothesis about the existence of age differences between the teachers can be discarded according to the $\chi 2$-test. The variance is explained by a statistically significant difference in the way of conduct between different age groups. The higher the age the higher the number of teachers who would take the sick leave or keep silent. None of the teachers surveyed up to 34 years would go to hospital, while $8.3 \%$ of those between 35 and 54 years and $25.0 \%$ of those over 55 years would have done so. A half of the oldest respondents would have accepted such situation and no one would consider changing the job. $42.4 \%$ of the surveyed teachers younger than 34 years would have sought a new position.

The difference between the answers is both obvious and expected. The teachers shortly before their retirement have only few opportunities of a new employment in another school. Therefore they do not see a solution in the replacement of the service or in any action in the case of harassment in the workplace. Most of them would keep silent or would seek refuge in a sick leave. The older teachers surveyed expressed their intention that they would "for these few years be patient", would do what they would have to do, but without any extra effort in work and in interpersonal relationships.

Although the employment, even in Slovenian elementary schools, is more and more difficult to get, the younger teachers surveyed think differently. In a large extent they would search for a new job $(42.4 \%)$. Also, because they estimate that they are more easily employable, have many innovative ideas, motivation and enthusiasm which give them an advantage on the labor market. More than a half of them are also convinced that if being victim of mobbing, they would bring an action against the attacker, which is definitely encouraging.

\subsection{Teachers and the mobbing offenders}

\begin{tabular}{|l|c|c|}
\hline Offender & f & f \% \\
\hline Leadership & 13 & 12,3 \\
\hline Colleagues & 3 & 2,8 \\
\hline Co-workers & 7 & 6,6 \\
\hline Parents & 4 & 3,8 \\
\hline Students & 5 & 4,7 \\
\hline None & 74 & 69,8 \\
\hline Total & 106 & 100,0 \\
\hline
\end{tabular}

Table 8 Number $(f)$ and percentage $(f \%)$ of offender types 


\section{Acta Technologica Dubnicae \\ volume 2, 2012, issue 1}

The school environment is free from classical subordination, which is typical for many other institutions with a specific and orderly position hierarchy. The headmaster of a school is superior to teachers and we recognized students and their parents as subordinates to teachers.

Since $14.2 \%$ of the respondents were identified as victims of mobbing in our study, significantly more respondents reported about perpetrators, we conclude that the respondents who had only observed mobbing responded to this question. The teachers most often recognized the superiors as the agents of bullying in their workplace. In $12.3 \%$ of all cases the headmaster or the school director was detected as a mobbing offender. Each headmaster leading the school wants to see "his" school reaching high, if not enviable, results. Achieving them is possible only if teachers are adequately trained, motivated for teaching as well as for the acquisition of new knowledge and their sustainable development. Only in this way they can be successful in the transfer of knowledge and skills to their students, in developing their potential and talents. As the schools compete for the affection of students and their parents, the schoolmaster often pushes on the teachers requiring and expecting too much of them. The teachers may feel such pressure threatening. If the school climate does not include the team spirit, if the manager cannot properly lead and guide their employees, an authoritarian leadership style could easily turn to mobbing.

The other teachers $(6.6 \%)$ often mobbed the interviewed teachers. This is a group of collaborators who associated in order to offload a certain person. The fact that mobbing was carried out by $4.7 \%$ of the students and by $3.8 \%$ of their parents is surprising in our research. This finding points to the pedocentristic attitudes and child's permissive education. Parents have become overprotective in educating their children, and do not trust and do not believe teachers like they did in past. Thus, parents are often willing to do everything to destroy a specific teacher psychically and to banish him/her from school. It would be interesting to learn about parents' reasons of the behavior to this teacher and which actions they use to mob him/her.

We were surprised by the fact that students stick out as mobbing offenders. Though there is a significant difference between teachers and students in age, the surveyed teachers stated that they are also by their students. We assume the falling students' respect, appreciation and recognition of teachers. We suppose that students mob teachers continually by rising their anxiety, not listening to them, not following the implementation of the lesson, avoiding to speak, scolding and break them... In short, the question of the teacher's authority quickly arises. And above all: Are modern teachers really no longer matches with pupils? Are they not able to work in changed circumstances and at the same time not able to build their professional authority and gain the trust of students?

\begin{tabular}{|c|c|c|c|c|c|c|c|c|c|c|}
\hline \multirow{2}{*}{ Offender } & \multicolumn{2}{|c|}{ Male } & \multicolumn{2}{|c|}{ Female } & \multirow{2}{*}{\multicolumn{2}{|c|}{$\begin{array}{l}\text { Up to } 34 \text { years } \\
\text { f f \% }\end{array}$}} & \multicolumn{2}{|c|}{$35-54$ years } & \multicolumn{2}{|c|}{$\begin{array}{c}\text { Over } 55 \\
\text { years }\end{array}$} \\
\hline & f & f $\%$ & f & f \% & & & & f \% & f & f \% \\
\hline Leadership & 2 & 11.8 & 11 & 12.4 & 1 & 3.8 & 11 & 15.3 & 1 & 12.5 \\
\hline Colleagues & 0 & 0.0 & 3 & 3.4 & 0 & 0.0 & 2 & 2.8 & 1 & 12.5 \\
\hline Co-workers & 3 & 17.6 & 4 & 4.5 & 2 & 7.7 & 4 & 5.6 & 1 & 12.5 \\
\hline Parents & 0 & 0.0 & 4 & 4.5 & 1 & 3.8 & 3 & 4.2 & 0 & 0.0 \\
\hline Students & 1 & 5.9 & 4 & 4.5 & 2 & 7.7 & 3 & 4.2 & 0 & 0.0 \\
\hline None & 11 & 64.7 & 63 & 70.8 & 20 & 76.9 & 49 & 68.1 & 5 & 62.5 \\
\hline Total & 17 & 100.0 & 89 & 100.0 & 26 & 100.0 & 72 & 100.0 & 8 & 100.0 \\
\hline$\chi^{2 \text {-test }}$ & & 5.402, & $5, p=$ & & & $\chi^{2}=$ & $75, \mathrm{~g}$ & $10, p=1$ & & \\
\hline
\end{tabular}

Table 9 Number $(f)$ and percentage $(f \%)$ of offenders by gender and age 


\section{Acta Technologica Dubnicae \\ volume 2, 2012, issue 1}

Based on the $\chi 2$-test, we found out that in both cases the null hypothesis is retained, which means that regardless of gender and age of the surveyed teachers we cannot speak of statistically significant differences of the mobbing perpetrator.

The frequency distribution showed us that $11.8 \%$ of male and $12.4 \%$ of female respondents said that the mobbing offender most often was the superior. A colleague attacked $3.4 \%$ of female teachers and no male teacher. A group of employees attacked $17.6 \%$ of male and $4.5 \%$ of female colleagues. We detected that the female teachers are more often attacked by a single person, probably because women are known as "less strong" and resist the attacker less than men. The teachers are often harassed by a group of employees, since men are identified as more virtuous and harder to be confused. Males are probably afraid to mob a single individual, as the offender fears a retaliatory attack. The group against an individual is of course an easier and more subtle form of bullying in the workplace. Parents, who frequently participate in the mobbing process together with their children, had harassed $4.5 \%$ of teachers. Students in about equal measure harassed both interviewed male $(5.9 \%)$ and female $(4.5 \%)$ teachers.

The interviewed teachers up to 34 years were in most cases mobbed by their colleagues $(7.7 \%)$ and students $(7.7 \%)$. The teachers between 35 and 54 years said that they most often had been abused by a parent $(15.3 \%)$. The surveyed teachers over 55 years have been mobbed by the supervisor and their colleagues by the same extent. It is noticeable that older teachers were still more respected as both students and students' parents did not mob them. Pupils frequently engaged the youngest teachers, knowing that they have less work experience with restless and distracting students that they learn about their work and are not familiar with the all methods to calm down the class yet.

\section{Conclusion}

The results of our study show that at least one of seven elementary school teachers has been already exposed to mobbing. The figure is alarming, because we have already indicated how serious the consequences of mobbing are on individuals and on the organization. A precise description and analysis of them are important for mobbing prevention. There are several different measures how to prevent mobbing effectively: improvement of the management style, delivering clear information, open communication, organization culture which commands the teamwork. Organization arrangement or psychological contract, as a special agreement between employers and employees, setting out the duties and responsibilities of the superiors in the detection of mobbing as well as sanctioning the offenders are particularly interesting forms of prevention. One solution to help victims is also the so called "open phone" (a 24-hour help line free of charge). Permanent, quality and content-relevant information and awareness of mobbing phenomenon, various public or organizational campaigns against mobbing and highlighting the current legislation are among the most effective means of prevention. A new Penal Code (PC-1) was adopted in Slovenia in 2008, which in the 197th Article accuses perpetrators of mobbing and sends them to prison for up to 2 years

Of course, more can be done by changing our minds and value system. Good interpersonal relations and cooperation with one another must become the highest value, not crowded out by the desire for higher wages and competition which are very much specific in consumer-oriented Slovenian postmodern society. Also, because it is right to "prevent mobbing in order to remain 'human', that we preserve human dignity at work and our personal integrity and thus remain a 'healthy society'... It is time to move to a better quality management with people at work. This does not mean that services will become more secure than ever, they can become a place of personal and professional development of individuals, which is their fundamental purpose" Brečko (2007, p. 427). 


\section{Acta Technologica Dubnicae \\ volume 2, 2012, issue 1}

However, the phenomenon of mobbing most often occurs in the environments characterized by:

- a highly competitive working environment with the "career" and with strong hierarchical structure;

- feeling of redundancy;

- dominated authoritarian style of leadership and management;

- weak and uncertain planning of organization changes;

- week and insufficient integration and participation of employees in decision-making;

- low potential for professional training or retraining;

- the lack of mutual respect, especially respect for cultural differences;

- the lack of clear rules at work and rules of behavior;

- an excessive workload and meaningless tasks, which are defined insufficiently and ambiguously;

- the detectable absence of employees' professionalism (Kostelić-Martić, 2005, p. 24).

We can conclude that the main finding of our research is the recognition and also a proof that the man is making himself a disservice if he is a helpless prisoner of the mobbing situation and that it is still significantly a higher risk if anyone in the workplace intentionally or unintentionally ignores it. In both cases the deviation is unacceptable; as the first means that the man does not take responsibility for what he does and what is happening to him, the other is owned by those who blindly trust in their own strength and self-sufficiency. As victims are usually responsible individuals with a sense of social justice and motivated people with a healthy personality tradition which was confirmed by the empirical data obtained. This fact needs a serious attention of both the so employees (teachers) and employers (the state), because only satisfied employees are successful workers, not only for themselves but for the society as a whole.

Therefore all the parties, without prejudice to the role of malicious, feel a real need for reconceptualization, and nobody and nothing can avoid it in the contemporary post-modern times. It is becoming increasingly clear that even simple decisions in primary schools which do not care only for students' education, but also for the health of the employees, must pass a test of legitimacy. If they do not comply with it, they can be replaced by others, which are freer and fairer and, above all, more human and man-oriented.

It is important that interpersonal space (especially in the modern globalized world) is essentially a plural space, a world of differences. Changed understanding, questions about the dimensions of humanity, the presence of many socially undesirable phenomena at the workplace and, consequently, the absence of health and reduced opportunities for a decent life and establishment of ethical space. The meeting place of teachers, students and parents is including the idea of changing world gaining new dimensions.

The resulting changes require reconsideration of acquisition and transmission of knowledge, methods of its evaluation and especially the social status of teachers. Certainly the new concepts of acquisition and transmission of knowledge require changes in organization of the subsystem itself, changes in attitudes, a new authority, power, autonomy and accountability. Work, organizational and professional autonomous processes simply should not be controlled by subjugation beliefs any longer. It seems that the reflection of new concepts of knowledge acquisition and dissemination should also include the utopian dimension, as the world without vision, without any instrumental utopia, is only realism and standstill. Therefore it is essential to provide enough space and scope for imagination. Where to find the reflection of impulses about "different" organization of work in primary education?

Because of the extreme dynamics of social changes which require reconceptualization of basic categories, it seems that the sphere of teachers' work, leadership management and a state with all its institutions, in particular, will undergo the reorganization of their work principles, as they will not be able to operate in old concepts any longer. Although, despite the constant changes in school system, 


\section{Acta Technologica Dubnicae \\ volume 2, 2012, issue 1}

the frames remain unchanged. But there is no longer space and time only for minor changes. The accumulated contradictions show that a solution is not possible only in (re)searching inside the old concepts. Apparently, with all the tendencies to provide as much as possible of the accumulated knowledge to the individual, many new and effective teaching strategies, techniques and methods of teaching and learning have been created. Unfortunately, we also have to note that the process of losing the fundamental mission of educational work and understanding of what is inherent to this work learning and training - has began.

In sharp economic and working situation, we perceive the growing commitment to the development of the ethics of participation, based on a professional conversation, which emphasizes the power of the participants in the process. An important element of such empowerment is the awareness that there exists a solution. In any case, the individual may exercise as a unique creature only if he/she is independent and free in his/her creativity and immanence. The independence is associated with the need to know how to take care of oneself and how to maintain control over our actions, how to control events around us and how to be aware of ourselves. And what is particularly interesting: that an individual is allowed to care for others. Especially the last idea shows sociality, an individual's need to be embedded in social networks, to be independent, but not to be attacked by an aggressor. Therefore it is not unusual that the protective factors which provide a teacher to be successful are those, which allow him/her to exercise being an operator and work autonomously. This includes acceptance, respect, compassion, interest and trust, and in particular understanding of the objectives and purpose of functioning and learning in the new perspectives.

\section{References}

BAKOVNIK, R.: Role of council workers in detecting and preventing mobbing. In: Industrial Democracy, vol. 5, 2006, no. 12, p. 3-5.

BARLE, A. - BEZENŠEK, J.: POGLAVJA iz sociologije vzgoje in izobraževanja: pregled sodobnih socioloških študij, perspektiv in konceptov. Koper: Fakulteta za management, 2006.

BEZENŠEK, J. - BARLE, A.: Poglavja iz sociologije medicine. Maribor: Medicinska fakulteta, 2007.

BREČKO, D.: "Mobbing" - psychological and emotional violence in the workplace. In: HRM, vol. 1, 2003, no. 1, p. 62-64.

BREČKO, D.: Mobbing - psychoteror competitive society. In: Industrial Democracy, vol. 5, 2006, no. 12, p. 12-18.

BREČKO, D.: Mobbing - how to recognize and act on time. In: Workers and employers, vol. 7, 2007, no. 2-3, p. 415-428.

BRINKMANN, R. D.: Mobbing, bullying, bossing: Triebjagd am Arbeitsplatz. Erkennen, Beeinflussen und Vermeiden systematischer Feindseligkeiten. Heidelberg: J. H. Sauer-Verlag, 1995.

Criminal Code (KZ-1, Uradni list RS št. 55, 4. 6. 2008).

CVETKO, A.: Mobbing - psychological violence. In: M. Fikfak Dodič (Ed.), Violence in the workplace. Ljubljana: Clinical Center, Clinical Institute of Occupational Medicine and Sport, 2006, p. 25-39.

DAVENPORT, N. - SCHWARTZ, R. - ELLIOTT, G.: Mobbing: Emotional Abuse and the American Workplace. Ames: Civil Society Publishing, 2005.

DODIČ FIKFAK, M. et al.: Violence in the workplace. Ljubljana: University Medical Centre, 2006.

EINARSEN, S. - SKOGSTAD, A.: Bullying at work. Epidemiological Findings in Public and Private Organizations. In: European Journal of Work and Organizational Psychology, vol. 5, 1996, no. 2, p. 185-201.

GRUBAN, B.: "People" or people with new values? (New) organizational culture and values. In: $H R M$, vol. 1, 2003, no. 1, p. 8-13.

KALČIČ, V. - KNAVS, N.: From hell to the Cancellation section. In: Diaries lens Annex newspaper Dnevnik, vol. 57, 2007, no. 125, p. 4-7.

KEČANOVIĆ, B.: Stop Violence in the workplace! In: $P P$, vol. 25, 2006, no. 49/50, p. 22-23. 


\section{Acta Technologica Dubnicae \\ volume 2, 2012, issue 1}

KNORZ, C. - ZAPF, D.: Mobbing: Eine extreme Form Sozialer Stressoren am Arbeitsplatz. In: Zeitschrift für Arbeits-und Organisationspsychologie, 1996, no. 1, p. 12-22.

KOIĆ, E.: Posljedice mobbing the psihičko zaposlenika you health. In: M. Dodič Fikfak et al. (Ed.), Violence in the workplace. Ljubljana: University Medical Centre, 2006.

KOSTELIĆ-MARTIĆ, A.: Mobbing: psihičko maltretiranje on radnome mjestu. Zagreb: Školska knjiga, 2005.

KOSTELIĆ-MARTIĆ, A.: Psychological violence in the workplace. In: HRM, vol. 5, 2007, no. 15, p. 26-32.

KRAJNC, J.: Rimsko pravo. Ljubljana: GV Založba, 2010.

LEYMANN, H.: Mobbing. Psychoterror am Arbeitsplatz und wie man sich dagegen kann Wehr. Reinbek bei Hamburg: Rowohlt Taschenbuch Verlag, 1993.

LEYMANN, H.: Der neue Mobbing-Bericht. Erfahrungen und Initiative, Auswege und Hilfsangebote. Reinbek bei Hamburg: Rowohlt Taschenbuch Verlag, 1995.

MARAIS-STEINMAN, S.: The Changing Workplace, 1998.

Retrieved 13. 9. 2008 from http://cw.co.za/tamun/change.

MLINARIĆ, P.: Protection against mobingom: When service becomes a hell. In: HRM, vol. 5, 2007, no. 15 , p. $34-38$.

NAMIE, G.: US hostile workplace survey.

Retrieved 14. 8. 2007 from http://workdoctor.com/home/twd/employers/surv2000.htm

NIEDL, K.: Mobbing/Bullying am Arbeitsplatz. Eine empirische Analyse zum Phänomen sowie zu personalwirtschaftlich relevanten Effekten von systematischen Feindseligkeiten. München: Rainer Hampp Verlag, 1995.

PARENT-THIRION, A. et al.: Fourth European Working Conditions Survey. European Foundation for the Improvenment of Living and Working Conditions, 2007, obtained 22nd 10th 2008, from http://www.eurofound.europa.eu/pubdocs/2006/98/en/2/ef0698en.pdf.

Penal Code (PC-1). Official Gazette, 55/2008.

Retrieved 3. 11. 2008 from http://www.uradni-list.si/1/index?edition=200855.

RESCH, M.: Wenn Arbeit macht krank. Berlin: Ullstein, 1994.

TUŠKEJ, M.: The role of personnel departments in the management of mobbing [Master's thesis]. Kranj: University of Maribor, 2007.

PURGAJ, T.: Some aspects of the prevalence of mobbing among teachers in elementary school [diploma thesis]. Kranj: University of Maribor, 2009.

ŠKRILEC, M.: The sociological aspects of the impact on the occurrence of workplace mobbing [Master's thesis]. Maribor: University of Maribor, 2008.

WEAVER, L.: Mobbing - psihoteror in the workplace. In: Industrial Democracy, vol. 5, 2006, no. 12, p. 6-12.

ZAPF, D.: Organisational, work group related and personal causes of mobbing / Bullying at work. In: International Journal of Manpower, vol. 20, 1999, no. 1-2, p. 70-85.

ZUSCHLAG, B.: Mobbing: Schikane am Arbeitsplatz. Göttingen: Verlag für Angewandte Psychologie, 2001. 